\title{
Information literacy skills among high school students: An exploratory study of six schools in the South East region of Botswana
}

\author{
Boemo Nlayidzi Jorosi, \\ Dept. of Library and Information Studies, \\ University of Botswana, Gaborone \\ Goitsemang Gladness Isaac, Library Services \\ University of Botswana, Gaborone
}

\begin{abstract}
Over the past four decades or so, information literacy skills have quickly gained centre-stage status in the educational sector as a strategy of coping with the overload of information. This study reports the results of an exploratory investigation $(N=279)$ into information literacy skills among final year high school students in six schools located in the south eastern Botswana. The objectives of the study were twofold: (1) to determine the information literacy level among final year students, and (2) to gain a broader understanding of information literacy skills practices in Botswana high schools. Data were gathered via self-administered questionnaires and additional qualitative data were obtained from structured interviews with teacher-librarians. Results indicate three main issues: first, poor information skills among the students; second, heavy reliance on the use of prescribed textbooks; and finally, the curriculum as a barrier towards the effective integration of information literacy skills into the educational system.
\end{abstract}

\section{Introduction}

Information literacy forms the basis for life-long learning. It is common to all disciplines, to all learning environments and to all levels of education. It enables learners to master content and extend their investigations, become self-directed and assume greater control over their own learning (American College and Research Libraries Task Force, 2000: 207). Librarians at schools, therefore, need to work together with the teachers to incorporate information literacy in the curriculum to form the basis for life-long learning. Through teaching and by leading discussions, the teachers should establish the context for learning. The teachers should also inspire students to explore the unknown, offer guidance on how best to fulfill information needs and monitor students' progress.

According to the American Association for School Librarians (1998), school librarians play the role of organizing and maintaining collections and many points of access to information. The school administrators should create opportunities for collaboration among the teachers, librarians and other professionals, to initiate information literacy programmes. The same administrators are to lead in planning and budgeting for information literacy programmes and provide ongoing resources to sustain them. The delivery of information over networks has necessitated quite refined skills for successful searching and the development of critical approaches to information selection and use (Underwood, 2000). As a result of this, there is a need to have more structured approaches to facilitate the acquisition of information literacy within the curriculum. Information 
literacy provides a basis for life-long learning which, if learnt at an early stage of learning, can also be useful, even in the workplace.

\section{Purpose of the study}

The purpose of the study was twofold. First, it intended to determine the levels of information literacy skills among high school students in Botswana, that is, students' general proficiencies in information handling skills in accordance with some of the established generic information literacy competencies. Second, the study also sought to gain a broader understanding of the information literacy practices in select high schools, i.e. to develop a deeper insight of how information literacy skills are delivered and their position vis-à-vis the curriculum.

\section{Rationale for the study}

The subject information literacy skills boasts an admirable four-decade history during which it has been a fertile ground for both researchers and practitioners seeking to better understand; among other things, the value and effectiveness of information handling skills to students and teaching and learning in general. In fact, considerable literature has been generated among which there are notable classics like Kuhlthau (1987); Doyle, (1992); Herring (1996); Bruce (2000) and many others.

However, although the impressive contributions of the extant literature are selfevident, the literature reveals some apparent limitations. First, much of the research has focused on higher education students (universities and colleges) (Herring, 1996). Second, the literature is dominated exclusively by studies that were conducted in developed nations such as the United States of America, the United Kingdom, New Zealand, Australia and Canada to name only but a few. To date few studies were uncovered which focus on a developing country context and none were found that address the Botswana context. Considerable relevant research on business management in developing countries suggests that the two contexts (developed country context and developing country context) are radically different (see for example; Fubara, 1986; Mrema, 1987 and Elenkov, 1997 for a detailed discussion). As a result of the few studies on information literacy skills developing country contexts, we know very little about the subject as it obtains in these situations. Thus this study sought to address this lacuna in the information literacy skills literature.

\section{Background to education in Botswana}

According to the Revised National Policy on Education (Botswana Government. Ministry of Education. 2005. http://www.gov.bw.moe Accessed 14/03/2005), the objectives of the Ministry of Education inter alia are to:

* raise educational standards at all levels.

* provide life-long education to all sections of the population.

* assume more effective control of the examination mechanism in order to ensure that broad objectives of the curriculum are realized. 


\section{Education system in Botswana}

The Ministry of Education in Botswana follows a 7+3+2 education structure. There are seven years of primary education, at the end of which pupils write the Primary School Leaving Examinations (PSLE). Almost all of these pupils proceed to Form One, which is the first year of the three years of the junior secondary school course. At the end of the Junior Certificate (JC) programme the students write examinations which determine entry into the senior secondary school curriculum. Education is made accessible in the first ten years of schooling to all the pupils to create opportunities for life-long learning, to enable individuals to attain their full potential and to contribute to the national socioeconomic development of the country. There are currently 27 senior Government secondary schools spread around the country.

In four of the school libraries there were five qualified librarians and in the other two there were two teacher librarians, with unqualified library attendants. There was generally little library usage among students at five of the schools. In at least at one school, teachers encouraged the students to use the library for school purposes. Communication with the librarians showed that the students relied too much on the teachers' notes and this resulted in students not using library books. There was no promotion of school library usage, and there were no library catalogues. All these contribute towards poor information literacy skills among the students. At all the schools, librarians emphasized that there was no rudimentary user education. According to the librarians in all schools, the administrators are very supportive of their mission and they always allocate funds from the budgets to improve the libraries. Overall, the schools in the study receive 5\% of the money from the budget allocated to the school to use for the library.

\section{Literature Review}

\section{Information literacy}

A thorough review of literature is beyond the scope of this paper for reasons of space and the considerable germane literature that exists on the topic at hand. Instead, we provide a purposefully brief and selective review of literature with a view to put our study into perspective.

The concept of information literacy emerged in the 1970s and has since been interpreted and described in many different ways by different scholars. Rader (1990: 20) defined information literacy as understanding the processes and systems for acquiring current and retrospective information, such as systems and services for information identification and delivery, as well as the ability to evaluate the effectiveness and reliability of various kinds of information channels and sources, including libraries, for various kinds of information needs and also mastering certain basic skills in acquiring and storing one's own information in such areas as databases, spreadsheets, as well as word and information processing. 
According to the Council of Australian University Librarians (2001:1) information literacy is defined as an understanding and set of abilities enabling individuals to "recognize when information is needed and have the capacity to locate, evaluate, and use effectively the needed information".

Information literacy aims to help students to locate materials for particular assignments. It also enables them to develop the ability to make use of the library resources for their information needs. It includes a variety of programmes of instruction, education and exploration, to develop in students the skills to make effective, efficient and independent use of the information sources, library resources and services available to them.

Information literacy is important because there has been a shift from teacher centered learning to student centered learning (Lwehabura, 1999). The students are, therefore, supposed to make effective use of the library for the assignments given to them by their teachers. It is now clear that the time when students relied entirely on the teachers' notes, without supplementing them with other sources, has come to an end. Atton (1994: 310) says that "education at all levels is now striving to develop the independent learner through a student-centered style of learning". Developing an independent learner needs to be encouraged at all levels of education and in this regard the present researchers concur with Atton. The idea of independent learning must be encouraged from the early stages of learning.

Libraries become useless if the users do not make effective and efficient use of them. Lwehabura (1999) emphasizes the fact that lack of meaningful information literacy programmes in many high school libraries contributes to incompetence in the effective use of library resources.

Bundy (1998) is of the view that what is clearly needed to accelerate interest in information literacy by teachers at all levels of education is tangibility and proof that it makes a difference to short- and long-term learning outcomes. Adding to that, Todd (1996: 3 ) points out that students become constructive thinkers, ask appropriate questions, and see information from a range of sources. Information literate students restructure and repackage the information they find, to create and communicate ideas that reflect their own deep understanding.

In summary, we conclude this review by highlighting a few salient contemporary issues in the literature on information literacy skills. Some of the current issues are: (1) the link between information literacy skills and academic achievement; (2) new roles for teacher librarians (3) the application of theoretical frameworks that guide educators and practitioners (e.g. the constructivist view) (4) the extolling of the virtues student/child-centered approach to learning.

\section{Research Design}


Since the study investigates a contemporary phenomenon in its contexts, a blend of data collection methods was considered suitable for this investigation. To this end, the study used case study methods of collecting and analyzing data: questionnaires, interviews and observation. Yin (1994), a leading scholar on case studies research describes a case study as an empirical study, which seeks to investigate a current phenomenon within its real life context. It was reasoned that such a combination of methods would provide cross validation of data, i.e. the use of multiple methods permits the exploitation of strengths of separate methods at the same time minimizing the inherent weaknesses of each method.

\section{Area and population of study}

The area of the study was the south east teaching district which according to the Ministry of Education includes schools around Gaborone and the immediate environs. The study involved multiple site case studies involving six high schools. The target population of the study was form five classes and teacher librarians from a sample of six schools in the area. The rationale for choosing form five students was that they were deemed to be the most suitable group to exhibit information literacy skills.

\section{Data collection}

Data collection for the study reported here took place between January and March 2005. Permission to gather data was sought from the principal of each school. After obtaining permission to carry out the investigation, a total of 290 coloured questionnaires were disseminated to a purposive sample of form five students, with the help of teacher librarians. According to Kent (2001), purposive samples are used quite legitimately for research in exploratory, qualitative or indeed experimental research where the focus is on understanding situations, generating ideas or evaluating social situations (Kent, 2001:140). Additional qualitative data were collected via structured interviews (Mintzberg, 1973), with teacher librarians, i.e. the investigators gathered first-hand rich qualitative data on a range of aspects relating to information literacy skills. Data from interviews were in turn complemented by observations on the library timetables, text books, reference sources, magazines and multimedia equipment used for teaching and learning. The collected data were coded and simple statistical tabulations were performed to produce descriptive statistics of frequency counts and percentages. In the section that follows, we present the key findings of the empirical study.

\section{Results of the study}

The analysis of the survey yielded a wealth of detailed data on each of the areas investigated. Space limitations do not permit reporting on the findings in great detail and so a series of brief summaries of analyses are presented.

\section{Profile of respondents}


Section A of the questionnaire included questions that collected brief background data on: age, gender and previous school attended by the study's subjects. Table 1 below depicts the demographic data of the survey respondents.

Table 1: Age and gender of the students

$N=279$

\begin{tabular}{|c|c|c|c|c|}
\hline Age & $\begin{array}{c}\text { Gender } \\
\text { Male }\end{array}$ & $\begin{array}{c}\text { Gender } \\
\text { Female }\end{array}$ & Totals & Percentage \\
\hline 16 & 4 & 7 & 11 & 6 \\
\hline 17 & 27 & 40 & 67 & 24 \\
\hline 18 & 80 & 81 & 161 & 57 \\
\hline 19 & 10 & 17 & 27 & 9 \\
\hline 20 & 5 & 5 & 10 & 3 \\
\hline $22+$ & 2 & 1 & 3 & 1 \\
\hline Totals & $\mathbf{1 2 8}$ & $\mathbf{1 5 1}$ & $\mathbf{2 7 9}$ & $\mathbf{1 0 0 \%}$ \\
\hline
\end{tabular}

As is evident from the above table, in relation to the age of the respondents, the vast majority of the students (81\%) were in the 17-18 years age range. This feature of the sample is unsurprising as it mirrors the government of Botswana's policy that requires that children start school when they are seven years old. Therefore, in practice, a child that starts school at the age of seven spends about seven years at primary school, three years at junior secondary and the last two years at high school, by which time, she or he will be 17-18 years of age.

With respect to the apparent though insignificant gender imbalance in the survey sample ( $54 \%$ female and $46 \%$ male), that too reflects a key feature of the national population, which is heavily skewed towards females.

\section{Competence in translating information problems}

Students were then asked various questions relating to their information literacy skills. Table 2 below reflects the students' ability in translating information problems into information needs.

Table 2: Students' approach to information related problems 


\begin{tabular}{|l|c|c|c|c|}
\hline \multicolumn{1}{|c|}{ Activity } & Always & Sometimes & Never & Total \\
\hline Work on your own & $151(54 \%)$ & $126(45)$ & $2(0.8 \%)$ & 279 \\
\hline Work in groups & $16(6 \%)$ & $221(79 \%)$ & $42(15 \%)$ & 279 \\
\hline Consult other students & $51(18 \%)$ & $214(76 \%)$ & $14(6 \%)$ & 279 \\
\hline Consult the teacher & $77(27 \%)$ & $152(55 \%)$ & $50(18 \%)$ & 279 \\
\hline Consult other people & $40(14 \%)$ & $151(54 \%)$ & $88(32 \%)$ & 279 \\
\hline
\end{tabular}

Table 2 above shows how students approach information, they prefer to work on their own than consult other people including their teachers, librarians, parents and siblings. An information literate student is able to access information efficiently and effectively according to American Association for School Librarians (1998) standards. The reflection on the above table does not conform to information literacy standards as stipulated by AASL.

\section{The occurrence of information activities undertaken by students}

The next question in the questionnaire gathered data pertaining to the frequency of a variety of information activities students performed in pursuit of information. The sample responses are summarized in table 3

Table 3: Frequency of activities undertaken by students

\begin{tabular}{|l|c|c|c|}
\hline \multicolumn{1}{|c|}{ Activity } & Often & Sometimes & Never \\
\hline $\begin{array}{l}\text { Used the library to find the relevant materials for } \\
\text { study }\end{array}$ & $95(34 \%)$ & $137(49 \%)$ & $47(17 \%)$ \\
\hline $\begin{array}{l}\text { Found useful/relevant material not specifically } \\
\text { prescribed }\end{array}$ & $76(27 \%)$ & $140(50 \%)$ & $57(20 \%)$ \\
$\begin{array}{l}\text { Needed information sources outside the school } \\
\text { library to materials related to school work }\end{array}$ & $95(34 \%)$ & $118(42 \%)$ & $66(24 \%)$ \\
\hline Asked the librarian for help & $19(7 \%)$ & $86(31 \%)$ & $171(61 \%)$ \\
\hline $\begin{array}{l}\text { Borrowed library materials from any other library } \\
\text { other than the school library }\end{array}$ & $54(19 \%)$ & $68(24 \%)$ & $157(56 \%)$ \\
\hline
\end{tabular}

As one of the indices of information literacy skills, students were asked about how they engaged in a range of activities in pursuit of information. As evident from the above table, by and large, respondents show a propensity to engage in information acquisition activities. For example, a large proportion of the students (232 or 83\%) either "often" or "sometimes used the library" to find relevant material for their studies. However, and rather disturbingly, a striking feature of the data is the proportion (47 or 17\%) who "never used" and the (171 or $61 \%)$ who never ask for the librarian help. This finding is inversely related to the development of information literacy skills. 


\section{Students' abilities in various information skills}

As the fourth question, respondents were asked to indicate their proficiency with respect to their abilities some selected information skills deemed to exhibit a facet of information skills competencies. Results to this question are presented below in table 4 .

Table 4: Abilities in various information skills

\begin{tabular}{|l|c|c|c|c|}
\hline \multicolumn{1}{|c|}{ Activity } & Very able & Able & Not able & Total \\
\hline Express your own ideas in writing & $120(43 \%)$ & $155(56 \%)$ & $4(1 \%)$ & 279 \\
\hline $\begin{array}{l}\text { Express other writers' ideas in your } \\
\text { own words }\end{array}$ & $28(10 \%)$ & $202(73 \%)$ & $49(17 \%)$ & 279 \\
\hline $\begin{array}{l}\text { Prepare a list of references to attach } \\
\text { to your written work }\end{array}$ & $46(16 \%)$ & $156(56 \%)$ & $78(27 \%)$ & 279 \\
\hline $\begin{array}{l}\text { Read and interpret information from } \\
\text { charts/diagrams or graphs }\end{array}$ & $121(43 \%)$ & $129(46 \%)$ & $32(11 \%)$ & 279 \\
\hline
\end{tabular}

Table 4 above depicts data relating to students' competencies in a variety of information skills. Taken as a whole, the data reveal that the sample respondents believed they were significantly "able" and "very able" to execute the information skills they were asked about. For example, (120 or $43 \%$ ) and (155 or 56\%) of the respondents indicated being able to express their ideas. Overall, this represents an aggregate positive response of (96\%) and this result suggests a positive indicator towards the development of the information literacy skills.

\section{Usage of different information sources}

Another indicator of competency in information skills is the use of a variety of information sources. Respondents were probed about the levels of usage of information sources. Table 5 below summarizes the responses.

Table 5: Use of different sources of information

\begin{tabular}{|l|c|c|c|c|}
\hline \multicolumn{1}{|c|}{ Sources } & Often & Sometimes & Never & Total \\
\hline Dictionary & $171(62 \%)$ & $75(26 \%)$ & $33(12 \%)$ & 279 \\
\hline Encyclopedia & $33(12 \%)$ & $119(43 \%)$ & $127(45 \%)$ & 279 \\
\hline $\begin{array}{l}\text { Books other than } \\
\text { prescribed textbooks }\end{array}$ & $37(14 \%)$ & $130(47 \%)$ & $112(47 \%)$ & 279 \\
\hline Journals & $44(16 \%)$ & $79(28 \%)$ & $156(57 \%)$ & 279 \\
\hline Newspapers & $89(32 \%)$ & $128(47 \%)$ & $62(23 \%)$ & 279 \\
\hline Magazines & $100(36 \%)$ & $127(46 \%)$ & $50(18 \%)$ & 279 \\
\hline Television & $95(34 \%)$ & $127(46 \%)$ & $56(20 \%)$ & 279 \\
\hline Radio & $73(27 \%)$ & $133(48 \%)$ & $68(25 \%)$ & 279 \\
\hline
\end{tabular}




\begin{tabular}{|l|c|c|c|c|}
\hline Videos & $46(17 \%)$ & $115(42 \%)$ & $118(44 \%)$ & 279 \\
\hline Internet & $4(17 \%)$ & $63(23 \%)$ & $168(60 \%)$ & 279 \\
\hline
\end{tabular}

As shown above, the students in the current study used the dictionary more often than any other source. Out of the six high schools in south east region, only two had audio/visual rooms, where students could use non-book materials. This is the reason why only 128 (59.7\%) of the students reported that they often used the video as a source of information. Many of the students indicated that they used the radio and television because they were available at home rather than at school. The results show that most of the sources were used "sometimes" rather "than often" which does not suggest habitual usage. Two features of the data warrant highlighting. The first is the high number of students (97 or $45.3 \%$ ) who "never used" an encyclopedia, arguably one of the most common and basic source of information in typical high school library. The second is the low usage use of the Internet. The latter could be a result of low technology uptake, whereby only few schools in the country have access to the Internet

\section{Information evaluation}

A final question in the survey was aimed at eliciting student's proficiency in a crucial high order skill which forms an integral part of information literacy. Merchants and Hepworth (2000:81) capture it well when they assert that there are many aspects of the "information society" that require certain skills and values in order to deal with information available. They further suggest that existing knowledge and evaluation skills must be employed, whether consciously or subconsciously to determine the most useful sources to approach and extract the most useful information and apply it in the most appropriate way. Table 6 below presents the sample responses.

Table 6: Students' ability to evaluate information

\begin{tabular}{|l|c|c|c|c|}
\hline \multicolumn{1}{|c|}{ Activity } & Very able & Able & Not able & Total \\
\hline $\begin{array}{l}\text { Select information sources to meet } \\
\text { your needs }\end{array}$ & $52(19 \%)$ & $146(52 \%)$ & $81(29 \%)$ & 279 \\
\hline $\begin{array}{l}\text { Evaluate the accuracy (i.e. truth, } \\
\text { reasonableness of information) }\end{array}$ & $36(13 \%)$ & $120(43 \%)$ & $123(44 \%)$ & 279 \\
\hline $\begin{array}{l}\text { Evaluate currency ( i.e. up to } \\
\text { dateness) of information }\end{array}$ & $21(8 \%)$ & $71(25 \%)$ & $187(67 \%)$ & 279 \\
\hline $\begin{array}{l}\text { Evaluate authority (i.e. author's } \\
\text { credentials) of information }\end{array}$ & $16(6 \%)$ & $40(14 \%)$ & $224(80 \%)$ & 279 \\
\hline
\end{tabular}

Table 6 depicts the results of the present study in which students were asked if they had the ability to evaluate information that they find. It is evident that students who claim to be "very able "are in the minority in all the categories of information evaluation. On the whole, respondents do not seem to have developed a modest proficiency in the skills set. 


\section{Discussion}

The preceding section has presented the analysis of data and highlighted the study's key findings. In this section, we provide a discussion of the study's salient findings. However, space limitations do not permit detailed discussions with reference to extant and pertinent literature consequently, and where appropriate, reference to literature is brief and our discussion focuses on interpretation.

Information literacy is a composite concept i.e. there are many facets of information literacy. Consequently, and because of the exploratory nature of our investigation, our study was deliberately restricted to a few key aspects of concept. Specifically, the study focused on the following competencies: the frequency of certain information activities, skills possessed by students, the sources utilized by students, and students' proficiency in evaluation. Taken together, these areas or aspects measure a broad understanding of information literacy. Data from the field paints a chequered picture of information skills among the study sample. First, data pertaining to certain information intensive activities suggest that the students in the sample do engage in the information intensive activities for example, in table 2, students 54 or $19 \%$ of the students indicated that they needed information sources outside their school libraries. Second, responses to the question about students' competencies paint a revealing picture (200 or $72 \%$ ) of the respondents confirmed being able to prepare a list of references sources, which is suggestive of finer information literacy skills.

Second, the use of sources by the research sample is instructive (see table 5). Field data shows that students utilize variety of information sources of which unsurprisingly the dictionary preponderates. It can be argued that the utilization of such a variety of information sources is systematic of "developed information skills". However, a staggering figure of 112 or $47 \%$ of the respondents indicated that they did not use any books other than textbooks. Clearly this does not augur well for the information literacy skills development. Interview data revealed that this state of affairs is encouraged by the curriculum which specifies textbooks to be used. When students write examinations, it is expected that the answers they give must come from these textbooks Finally, evaluation, a high order thinking skill is by and large performed fairly well by the sample. Save for the evaluation of currency and authority which scored a high percentage of "not able " $65 \%$ and $79 \%$ respectively.

\section{Conclusion}

The study reported herein was an inquiry into the information literacy skills among senior high school students in eight secondary schools in southern Botswana. Information literacy skills were measured by the following competency indices: the frequency of certain information services, (2) the skills possessed by the students, (3) the sources utilized by the students, (4) students ability in evaluating information sources, and (5) the use of select information services.

The first significant finding of our study is that our respondents had poor information literacy skills. An analysis of the information literacy indices revealed that at least the majority of the respondents lacked ability in the key competencies they were being assessed. This finding confirms a recurring concern in the sparse literature on school 
libraries in Botswana that there is little or no library instruction in senior secondary schools in Botswana (Nametsegang, 1997; Serema, 1999).

Another important finding is the usage of textbooks by students. A large number of respondents (112 or 47\%) indicated that they never used any books other than the recommended textbooks. Interview data revealed that the curriculum was in fact a barrier in the development of information literacy skills as it fostered heavy reliance on textbooks.

Finally, our study represents an important preliminary step in understanding information literacy skills in a developing context which is fundamentally different from a developed context (e.g. resource munificence, technology uptake or ICTs adoption, economic conditions and education and training). Notwithstanding its third world focus, our study suggests that if information literacy skills are to be effectively integrated into the curriculum, there is a need for a curriculum redesign to ensure that teachers can use a variety of teaching methods that are consistent with the resource-based view of teaching and learning (American Association of School Librarians [AASL], 1996, p.1).

\section{Implications}

Although essentially a preliminary probe, the study reported here has two significant implications. The first implication concerns local tertiary institutions such as colleges of education, the University of Botswana and the institutes of health sciences where the vast majority of form five school leavers proceed to, in order to further their education. Our study reveals that students have poor information literacy skills.

Consequently, as recipients of college-bound freshmen with poor information literacy skills it is incumbent upon these institutions to design aggressive programmes and strategies to develop strong information literacy skills. The second implication albeit somewhat related to the former concerns the teaching methods and strategies employed by teachers in secondary schools. Presently, these teaching methods do not encourage the active use of the library and information resources, thus thwarting the development of information literacy skills. Teachers therefore need to change their teaching strategies to incorporate the use of information sources and services, and critical thinking and thus contribute to the development of information literacy skills.

\section{Limitations}

The findings of this study were drawn from self-administered questionnaires. Questionnaires are research instruments which permit self-reporting of individual perceptions. Consequently, they do not always represent what actually happens. Another limitation of the research was that a convenience sample of students was used. However, convenience samples are dogged by an inherent weakness of representativeness. In spite of these weaknesses, the investigations supplemented the data gathered with interviews with teacher-librarians and the fact that government schools follow a uniform curriculum and receive funding from the same source means that our samples were near homogenous. 


\section{References}

American Association of School Librarians (1996) Position statement on information literacy: A position paper on information problem solving [On-line]. Available: http://www.ala.org/aasl/positions/PS infolit.html.

American Association of School Librarians. (1998). Information power: building partnerships for learning. Chicago: AASL.

American College and Research Libraries Task Force. (2000). Information literacy competency standards for higher education: the final version. College and Research Libraries News 61 (3): 207-15.

Atton, C. (1994). Using critical thinking as a basis for library user education. Journal of Academic Librarianship, 20, 5 (6): 310-313.

Botswana Government. Ministry of Education. 2005. http://www.gov.bw.moe Accessed 14/03/2005),

Bruce, C. (2000). Information literacy research: dimensions of the emerging collective consciousness. Australian Academic Research L libraries, 31 (2): 91-109.

Bundy, A. (1998). Information literacy: the key competency for the $21^{\text {st }}$ Century. Paper presented at the Annual Conference of the International Association of Technological University Libraries held in Pretoria South Africa June 1998. Available at http://www.library.unisa.edu.au/papers/inlit21.htm [21/10/2002].

Council of Australian University Librarians. (2001). Information literacy standards. Canberra: CAUL.

Doyle, C. (1992). Outcome measures for information literacy within the National Education Goals of 1990. Final Report to National Forum on Information Literacy. Summary of findings, ERIC Reproduction Service.

Dragaon, P. \& Stevens, G. (1996). Developing life-long learners: an integrative and developmental approach to information literacy. Research Strategies. 14 (2): 68-81.

Elenkov, D.S. (1997). Strategic uncertainty and environmental scanning: the case for institutional influences on scanning behaviour. Strategic Management Journal. 18(4):287-302.

Fubara, B.A. (1985).Corporate planning in Nigeria. Long Range Planning. 19(2):125-132.

Herring, J. (1996). Teaching information skills in schools. London: Library Association.

Kent, R. (2001). Data construction and data analysis for survey research. Basingstoke: Palgrave.

Kulthau, C.C. (1987). An emerging theory of library instruction. School Library Media Quarterly. 16(1):2327.

Lwehabura, M. J. F. (1999). User education and information skills: a need for a systematic programme in African University libraries. African Journal of Library, Archives and Information Science, 9 (2): 129-14. 
Merchant, L. and M. Hepworth. (2002). Informaton literacy of teachers and pupils in secondary schools. Journal of Librarianship and Information Science, 34 (2): 81-89.

Mintzberg, H.D. (1973). The nature of managerial work. New York: Harper.

Mrema, E.L. (1987). Strategic planning in Tanzania. Long Range Planning. 20(3): 105-110.

Nametsegang, N. P. (1997). Attitudes of secondary school administrators towards school librarians and school library service: a survey of Botswana senior secondary schools. LIS thesis. Gaborone: University of Botswana.

Rader, H. (1990). Bibliographic instruction or information literacy. College and Research Libraries News, 51 (1): $18-20$.

Serema, B. C. (1999). School libraries in Botswana. The School Librarian, 47 (4): 183.

Todd, R. (1996). Independent learning and information literacy: an essential partnership for learning. In Nimon M. (ed.) Learning resourcefully: challenges for teacher librarians in the information age. Adelaide: Auslib Press: 3-18.

Underwood, P. G. (2000). Unfinished business: the InfoLit Project of the Adamastor Trust. Innovation, 21: $15-21$.

Yin, R. (1994). Case study research: design and methods. Thousand oaks, CA: Sage Publications. 
Reproduced with permission of the copyright owner. Further reproduction prohibited without permission. 